\title{
Factors Affecting Interests of Adolescent Visit in Poly PKPR (Health Care Service) Public Health Gondang Legi Malang District
}

Evi Kurniawati, Nurwijayanti, Agusta Dian Ellina

Master Program of Public Health, Institute of Health Sciences, Strada Indonesia

Email:

evikurniawati97@gmail.com

Received: October 5, 2020

Accepted : November 25, 2020

Published : November 30, 2020

This is an open-acces article distributed under the terms of the Creative Commons Attribution-ShareAlike 4.0 International License.

\begin{abstract}
A person's interest in services is related to the ability of these service providers to provide care. Interest in adolescents to take advantage of adolescent health care services is influenced by several factors, including perceptions, peers and the role of health workers in the service at puskesmas. The purpose of this study was to analyze the factors that influence the interest of teenage return visits at the PKPR (Youth Caring Health Services) Gondang Legi Health Center in Malang Regency. The design of this study was an observational quantitative study with a cross sectional approach with the focus of the research directed to be analyzing perceptions, the role of peers and the role of health workers on the interest of teenage return visits at the PKPR (Youth Care Health Services) Gondang Legi Public Health Center Malang Regency with a population of 167 respondents and a sample of 113 respondents taken by accidental sampling technique. The findings found that the majority of respondents had less categories of perception as many as 57 respondents $(50.4 \%)$. In addition, the majority of respondents had the role of less peer categories of 45 respondents $(51.3 \%)$. In addition, most respondents had the role of health workers in the good category of 59 respondents $(52.2 \%)$. While the majority of respondents had a high interest category of 62 respondents (54.9\%). The results of the study using the Logistic Regression Test showed that a p-value of $0,000<0.05$ then $\mathrm{H} 1$ was accepted so it was concluded that there was simultaneously the influence of perception, the role of peers and the role of health workers on the interest of teenage returnees in the PKPR (Youth Care Health Services) ) Gondang Legi Health Center in Malang Regency. The perspective of the patient regarding the available health services raises their perceptions. All friends will make an impact on individuals. And the provision of special services to adolescents through special treatment tailored to the desires, tastes and needs of adolescents has not been implemented
\end{abstract}

Keywords: Interests, perception, health officers, peers.

Copyright (C) 2020 IIK STRADA Indonesia All right reserved. 


\section{BACKGROUND}

Health problems faced by adolescents in Indonesia include the increasing number of adolescents with HIVAIDS, Sexually Transmitted Infections (STIs), Unwanted Pregnancy (KTD) and drug abuse (Ministry of Health RI. 2005). According to BAPPENAS, UNFPA and BKKBN data, it is known that half of the 63 million adolescents aged 10 to 24 years in Indonesia are vulnerable to unhealthy behavior. One of the most prominent among teenagers today, is the problem of sexuality (pregnancy out of wedlock, abortion, infected with sexually transmitted diseases) and drug abuse (BKKBN. 2015).

Problems with adolescent behavior based on the 2012 STBPL were recorded from a sample taken that as many as $7 \%$ of the youth population in the past week, claimed to have had sex. $7 \%$ of teens who have had sex, $51 \%$ of them claimed to use a condom at the last sex. In addition, $4 \%$ of adolescents claimed to have tried using drugs, and the most frequently tried was marijuana. As many as $0.4 \%$ of adolescents claimed to use injecting drugs. Sexual intercourse and injecting drug use are potential for HIV-AIDS transmission among adolescents (Ministry of Health RI. 2017).

The survey produced by the Ministry of Health in 2016, 2.21\% or around 4.02 million people in 2010 and $2.8 \%$ around 5 million people of Indonesia were involved in drug abuse. Until the end of June 2016, there were 26,843 AIDS cases in Indonesia, with the largest sufferers aged 20-29 years with a percentage of $36.4 \%$ of the total AIDS sufferers. Based on these explanations it can be concluded that the occurrence of infection is when adolescents at the age of 15-24 years (Ministry of Health Republic of Indonesia 2016).

The causes of adolescent health problems are due to lack of access to adolescent health services, which includes lack of facilities, adolescents do not know if they have problems, adolescents do not know there are facilities, adolescents know but are not accessible (time, cost, coming must be with parents), adolescents know there is access but unwilling (long waiting time, unfriendly staff) (Central Provincial Health Service 2017). Teenagers prefer to overcome their own problems (51.08\%) than to come to health services $(23.42 \%)$. But almost all respondents $(94.56 \%)$ stated that they needed a youth service center. Only $31.4 \%$ of adolescents in Central Java had received reproductive health counseling (Ministry of Health Republic of Indonesia. 2015).

The handling of adolescent problems in Indonesia has been pursued despite its many shortcomings. The strategy for implementing adolescent health policies is carried out by the government through cross-sectoral cooperation, basic health services and their referrals, intervention patterns. This strategy has certainly been adjusted to the needs of the stages of the process of adolescent development and development (Ministry of Health Republic of Indonesia. 2018).

One of the strategies set to implement the policy is the implementation of adolescent health development carried out through effective and efficient youth involvement so as to achieve optimal results. Adolescent health services are carried out proactively through the implementation of Youth Care Health Services (PKPR) (Ministry of Health Republic of Indonesia. 2015).

Adolescent Health Care Services (PKPR) is a model of health services for adolescents in Puskesmas developed by the Family Health Directorate of the Indonesian Ministry of Health. The success of PKPR implementation is influenced by the involvement of all parties, starting from the government as policy maker, program implementer, community and youth (Ministry of Health Republic of Indonesia 2015).

A model of adolescent health services called the Adolescent Health Care Services (PKPR) has been developed by the Indonesian Ministry of Health since 2003. Counseling services and enhancing adolescent's ability to apply Education and Healthy Life Skills (PKHS) are some of the characteristics of adolescent health care services. This program is more engaged in providing information about adolescent health through institutions such as Youth Organizations, School Health Units (UKS), or youth cadre organizations formed by Community Health Center (Puskesmas). The delivery of adolescent health services is carried out according to the wants and needs of adolescents. (MOH RI, 2016)

Teenagers are also limited in access to get the right services and information. This is due to environmental factors that cause risk behaviors in adolescents that can threaten the ability of adolescents as a regenerating eye for the existence of human beings. One of them is harmful information that is easily accessed, this happens along with the rapid flow of information through various print and electronic media. Even though there is a lot of positive information, often the 
information provided cannot be justified, for example because it is incomplete, incorrect, incorrect and misleading. Another factor of the lack of adolescent access to information about reproductive health is social and cultural barriers.

Adolescent health programs are currently more engaged in providing information. The provision of special services to adolescents through special treatment tailored to the desires, tastes, and needs of adolescents has not been implemented. Thus, adolescents need to be actively involved in planning, implementing, and evaluating services. Ideas and concrete actions of adolescents will be more striking in planning and implementing services because they understand their needs. (Ministry of Health RI. 2018).

\section{METHOD}

In this study, researchers used a quantitative analytic design with a cross sectional approach which is a study to study the dynamics of the correlation between risk factors and effects, by way of approach, observation or data collection at a time (point time approach), that is, each subject the study was only observed once and measurements were made on the character status or subject variables at the time of examination. This study will analyze the factors that influence the interest of teenage return visits at the PKPR (Youth Caring Health Care) Clinic in Gondang Legi Health Center, Malang Regency.

Total population of 167 respondents and a sample of 113 respondents taken by accidental sampling technique. Data analysis uses the Logistic Regression test.

\section{RESULT}

Table 1. The results of statistical tests of factors affecting the interest of teenage return visits at the PKPR (Youth Caring Health Services) Gondang Legi Health Center in Malang District held on January 17 - February 17, 2019 with 113 respondents

\begin{tabular}{cccc}
\hline Variabel & $\alpha$ & Sig & B \\
\hline Perception & & 0.007 & 1.190 \\
The role of Peers & 0.05 & 0.006 & 0.810 \\
The Role of Health Officers & & 0.023 & 0.929 \\
\hline
\end{tabular}

\section{Binary}

1. Influence of perception of interest

Based on the results of the Binary Logistic Regression analysis of the variable perception of interest shows that the p-value of $0.007<0.05$ then $\mathrm{H} 1$ is accepted so it is concluded that there is an effect of perception on the interest of teenage returnees at the PKPR (Youth Caring Health Services) Health Center in Gondang Legi Malang Regency.

2. The influence of the role of peers on interests

Based on the results of Binary Logistic Regression analysis, the role of peers variable towards interest shows that the p-value of $0.006<0.05$, then $\mathrm{H} 0$ is rejected and $\mathrm{H} 1$ is accepted, so it is concluded that there is an influence of peer role on the interest of teenage returnees in the PKPR (Youth Care Health Services) ) Gondang Legi Health Center in Malang Regency.

3. Influence of the role of health workers on interests

Based on the results of the Binary Logistic Regression analysis the role of health workers variables towards interest shows that a p-value of $0.023<0.05$ then $\mathrm{H} 0$ is rejected and $\mathrm{H} 1$ is accepted so it is concluded that there is an influence of the role of health workers on the interest of teenage returnees in the PKPR (Youth Care Health Services) ) Gondang Legi Health Center in Malang Regency.

\section{Multivariat}

Based on the results of the Binary Logistic Regression analysis the peer role variable to interest shows that a p-value of $0.006<0.05$ then $\mathrm{H} 0$ is rejected and $\mathrm{H} 1$ is accepted so it is concluded that the peer role variable is most influential on the interest of teenage returnees in the PKPR (Health Care Services) Teens) Gondang Legi Health Center in Malang Regency. 


\section{DISCUSSION}

\section{Youth Perception in PKPR (Youth Care Health Services) Gondang Legi Community Health Center, Malang Regency}

The results showed that the majority of respondents had less category perceptions of 57 respondents (50.4\%). Whereas 56 respondents $(49.6 \%)$ had good category perceptions. Based on the results of cross tabulation between sex and perception, it was found that almost half of respondents who were female had good category perceptions of 38 respondents (33.6\%). In addition, a number of 36 respondents (31.9\%) who were female had a perception of the less category. In addition, a number of 21 respondents $(18.6 \%)$ who were male had a poor perception of the category. While 18 respondents (15.9\%) who were male had a good category perception.

Based on the results of cross tabulation between age and perception it was found that a small proportion of respondents aged 20-21 years had good category perceptions of 24 respondents $(21.2 \%)$. In addition, a number of 23 respondents $(20.4 \%)$ who were 16-17 years old had less category perceptions. In addition, a number of 21 respondents (18.6\%) who were 18-19 years old had less category perceptions. In addition, a number of 18 respondents (15.9\%) aged 18-19 years had good category perceptions. In addition, a number of 14 respondents (12.4\%) aged 16-17 years had good category perceptions. While a number of 13 respondents (11.5\%) aged 20-21 years had less perception of the category.

According to researchers, perception is a direct response to an absorption or process someone knows several things through sensing. Perception is also a process of observing a person towards the environment by using the senses that he has so that he becomes aware of everything in his environment. Which is if a person encounters something then he will judge in his own way. Based on the results of the study, it was found that the majority of respondents had inaccurate perceptions about adolescent health care services at the Gondang Legi Health Center in Malang Regency. Where the respondents considered that the activity was less needed and the respondents also considered that it was easier to find information from social media compared to the PKPR Poly. However, among those who rated it, almost half of the respondents rated that the existence of the PKPR Poly made it easy for teens to find good and correct information about health related to male and female adolescents. So many have good category perceptions.

Based on the results of the cross tabulation it can be explained that more female patients tend to have good perception. But there are also many female patients who have less perception. Poor perception of female sex is caused by high emotions in female patients. Where patients with female sex are more sensitive to feel the service that is felt less or better than health facilities provided. Whereas in the age characteristics, patients with the age of 20-21 years tend to have good perception, but at the age of 16-19 years tend to have more perceptions where it is caused at an age that tends to be younger still lacks the right attitude in using PKPR health facility.

\section{The Role of Teenage Peers in PKPR (Youth Care Health Services) Gondang Legi Health Center in Malang Regency}

The results showed that the majority of respondents had the role of peer categories less than 45 respondents $(51.3 \%)$. While a number of 55 respondents $(48.7 \%)$ had the role of peers in both categories. Based on the results of cross tabulation between sexes and the role of peers it was found that almost half of the respondents who were female had the role of peers in the less category category of 40 respondents (35.4\%). In addition, a number of 34 respondents $(30.1 \%)$ who were female had the role of peers in the good category. In addition, a number of 21 respondents $(18.6 \%)$ who were male had a good category of peer role. While a number of 18 respondents (15.9\%) who are male have the role of peers in the less category.

Based on the results of cross tabulation between age and the role of peers it was found that a small proportion of respondents aged 16-17 years had the role of peers in the less category category by 25 respondents $(22.1 \%)$. In addition, a number of 23 respondents $(20.4 \%)$ aged $18-19$ years had the role of peers in the good category. In addition, a number of 20 respondents (17.7\%) aged 20-21 years had the role of peers in the good category. In addition, a number of 17 respondents (15\%) aged 20-21 years had the role of peer categories less. In addition, a number of 16 respondents (14.2\%) aged 18-19 years had the role of peers in the less category. Whereas 12 respondents (10.6\%) aged 16-17 years had the role of peers in the good category. 
According to researchers in peer groups, someone tries to find his own concept. Here he is judged by his peers without regard to sanctions. Peer groups provide an environment, which is a world where adolescents do socialization where the values that apply are not values set by adults, but by peers.

Based on the results of the study it was found that many respondents who have the role of peers in the less category where it is caused because peers tend to suggest doing something less useful for the future and tend to do negative activities more often. Where adolescent peers are more open to issue all their complaints and do fun activities together to make stress coping from school burdens and burdens in the home environment. However, almost half of the respondents also have the role of good peers where the activities undertaken tend to be positive and help one another when one of the themes experiences a problem. So peers will advise you to check with the PKPR Poli if there are perceived irregularities related to adolescent reproductive health.

\section{The Role of Health Officers in Adolescents in the PKPR (Youth Caring Health Services) Gondang Legi Health Center in Malang Regency}

The results showed that the majority of respondents had the role of health workers in the good category of 59 respondents $(52.2 \%)$. While a number of 54 respondents $(47.8 \%)$ had the role of health workers in the less category.

According to researchers responsible health workers must be able to play an active role in improving the quality of the health of surrounding communities. In this based on the results of the study found that the majority of respondents said the role of health workers in the good category where it can be seen in terms of services that always provide good and friendly service. Health workers also often provide advice and input so that teens often go to the PKPR Poli so they can monitor their health regularly. However, there are some respondents who assess the role of health workers each less where it is due to the limited access of health workers to be able to reach directly to schools where there are many adolescents who have bad eating patterns, sleep patterns and patterns of activity to the association.

\section{Interest in Teenage Return Visit at PKPR (Youth Care Health Services) Gondang Legi Community Health Center, Malang Regency}

The results showed that the majority of respondents had a high interest category of 62 respondents $(54.9 \%)$. Whereas 51 respondents $(45.1 \%)$ had low interest categories. Based on the results of cross tabulation between sexes and interests it was found that almost half of respondents who were female had a high interest category of 40 respondents (35.4\%). In addition, 34 respondents (30.1\%) who were female had a low interest category. In addition, a number of 22 respondents $(19.5 \%)$ who were male had a high interest category. While 17 respondents $(15 \%)$ who were male had a low interest category.

Based on the results of cross tabulation between age and interest it was found that a small proportion of respondents aged 20-21 years had high interest categories of 24 respondents $(21.2 \%)$. In addition, a number of 23 respondents (20.4\%) aged 18-19 years had high interest categories. In addition, a number of 22 respondents (19.5\%) who were 16-17 years old had low interest categories. In addition, a number of 16 respondents (14.2\%) aged 18-19 years had low interest categories. In addition, a number of 15 respondents (13.3\%) who were 16.17 years old had a high interest category. Whereas 13 respondents (11.5\%) aged 20-21 years had low interest categories.

According to health service researchers must have a variety of basic requirements, namely the basic requirements that affect the community, especially adolescents in determining their choice of the use of health services. Services needed by adolescents in general are health services that are easily accessible and sustainable, health services must be reasonable and can be received by adolescents, locations easily accessible to the public, services provided are affordable and perfection of health services organized. Good service will attract people who want to use health facilities repeatedly without worrying about things they don't want.

Based on the results of the study, it was found that the majority of respondents had high interest which was due to their perception of health services to adolescents in the PKPR Poli. In addition, because a friend invited him to the PKPR Poli, the respondents felt happy to conduct an examination at the Poli. However, there are some respondents whose interest is low where it is caused 
because respondents feel better looking for their own information to social media than having to bother going to the PKPR Poly.

Based on the results of the cross tabulation it can be explained that patients who are female tend to have high interest, but there are still many female respondents who have low interest. Where this is due to the sensitivity of the perception of female patients in terms of absorbing services provided by health workers, female patients want the health services provided to be better.

\section{Influence of Perception on Interest in Teenage Re-Visitation at PKPR (Youth Caring Health Services) Gondang Legi Community Health Center, Malang Regency}

Based on the results of the analysis Based on the results of the Binary Logistic Regression analysis of the perception variable of interest shows that the p-value of $0.007<0.05$ then $\mathrm{H} 1$ is accepted so it is concluded that there is an effect of perception on the interest of teenage returnees at the PKPR (Youth Caring Health Services) Gondang Legi Health Center Malang Regency.

Based on the results of the cross tabulation between the variables of perception with interest it was found that almost half of respondents who had a good category perception also had a high interest category of 40 respondents (35.4\%). In addition, a number of 35 respondents (31\%) who had less category perceptions also had low interest categories. In addition, a number of 22 respondents $(19.5 \%)$ who had less category perception also had high interest categories. Whereas 16 respondents (14.2\%) who had good category perceptions also had low interest categories.

According to researchers the perspective of the patient regarding available health services raises their perceptions, good service will infer their perceptions or perspective as well. So therefore health facilities must arrange good services by prioritizing patient satisfaction so that patients feel satisfied with the services provided by health workers so that patients are interested in making a repeat visit to the nearest health facility without having to look for other health facilities. One's perception will affect one's interest in using a health service so that it is in accordance with the results of the study, which is the effect of perception on the interest of a teenage visit to the PKPR (Youth Care Health Services) Gondang Legi Health Center in Malang Regency.

\section{The Influence of Peers' Role on Interest in Teenage Re-Visit in PKPR (Youth Caring Health Services) Gondang Legi Health Center in Malang Regency}

Based on the results of the Binary Logistic Regression analysis the peer role variable to interest shows that a p-value of $0.006<0.05$ then $\mathrm{H} 0$ is rejected and $\mathrm{H} 1$ is accepted so it is concluded that there is the most significant influence of the peer role on the interest of teenage returnees in the PKPR (Health Services Poly) Youth Care) Gondang Legi Health Center, Malang Regency.

Based on the results of the cross tabulation between the variables of the role of peers with interest it was found that almost half of respondents who had the role of peers in the good category also had a high interest category of 45 respondents (39.8\%). In addition, a number of 41 respondents (36.3\%) who had the role of peers in the less category also had low interest categories. In addition, a number of 17 respondents (15\%) who had the role of peers in the less category also had high interest categories. While 10 respondents $(8.8 \%)$ who have the role of peers in the good category also have low interest categories.

According to researchers all friends will have an impact on individuals. If the theme is good, the individual will do good activities. Vice versa if he is friends with friends who are not good then the individual will tend to do negative activities as well. Where here the role of peers will greatly affect the night attitude individuals. Where according to the results of the study, there is an influence of the role of peers on the interest of teenage return visits at the PKPR (Youth Care Health Services) Gondang Legi Health Center in Malang Regency.

\section{The Influence of the Role of Health Officers on Interest in Teenage Re-Visitation at PKPR (Youth Care Health Services) Gondang Legi Health Center, Malang Regency}

Based on the results of the Binary Logistic Regression analysis the role of health workers variables towards interest shows that a p-value of $0.023<0.05$ then $\mathrm{H} 0$ is rejected and $\mathrm{H} 1$ is accepted so it is concluded that there is an influence of the role of health workers on the interest of teenage 
returnees in the PKPR (Youth Care Health Services). Gondang Legi Health Center in Malang Regency.

Based on the results of the cross-tabulation between the role of health staff variables with the interest, it was found that almost half of the respondents who had the role of a good health worker category also had a high interest category of 50 respondents (44.2\%). In addition, a number of 42 respondents $(37.2 \%)$ who had the role of health workers in the less category also had low interest categories. In addition, a number of 12 respondents $(10.6 \%)$ who had the role of health workers in the less category also had high interest categories. Whereas 9 respondents $(8 \%)$ who had the role of health workers in the good category also had low interest categories.

Adolescent health programs are currently more engaged in providing information. The provision of special services to adolescents through special treatment tailored to the desires, tastes, and needs of adolescents has not been implemented. Thus, adolescents need to be actively involved in planning, implementing, and evaluating services. Ideas and concrete actions of adolescents will be more striking in planning and implementing services because they understand their needs. Based on the results of research where there is an influence of the role of health workers on the interest of teenage return visits in the PKPR (Youth Care Health Services) Gondang Legi Health Center in Malang Regency.

\section{CONCLUTION}

1. Most respondents have less category perception as many as 57 respondents $(50.4 \%)$.

2. Most respondents have the role of peers in the less category category by 45 respondents $(51.3 \%)$.

3. Most respondents have the role of health workers in the good category of 59 respondents $(52.2 \%)$.

4. Most respondents have a high interest category of 62 respondents $(54.9 \%)$.

5. There is an influence of perception on the interest of teenage return visits at the PKPR (Youth Caring Health Services) Gondang Legi Community Health Center in Malang Regency.

6. There is an influence of the role of peers on the interest of teenage return visits at the PKPR (Youth Cares Health Care) Puskesmas Gondang Legi Malang Regency.

7. There is an influence of the role of health workers on the interest of teenage return visits at the PKPR (Youth Caring Health Services) Gondang Legi Puskesmas Malang Regency.

\section{SUGESTION}

1. For Respondents

It is expected that respondents can provide constructive feedback and criticism so that the services provided can be as expected.

2. For Educational Institutions

It is hoped that educational institutions can use the results of this study as learning inputs in the factors that influence the interest of teenage return visits in the PKPR (Youth Care Health Services) Gondang Legi Health Center in Malang Regency and can be developed further for further research to be more useful for readers and researchers .

3. For further researchers

It is hoped that further researchers will need to deepen and add more specific research on the factors that affect satisfaction in the PKPR (Youth Care Health Services) Gondang Legi Community Health Center in Malang Regency

\section{ACKNOWLEDGMENTS}

I say thank you to the respondent who are willing to be respondents in this study.

\section{CONFLICT OF INTEREST}

Nothing

\section{REFERENCES}

BKKBN. (2015). Pendataan Perilaku Remaja dan Aktifitas saat Berpacaran.

Ministry of Health RI. (2016). Data Dasar Puskesmas. Jakarta: Kementerian Kesehatan Republik Indonesia.

Ministry of Health RI. (2016) Rencana Strategi Kementerian Kesehatan. 
Nidia. (2017) Pengaruh Kualitas Layanan Jasa Kesehatan Terhadap Kepuasan Pasien Puskesmas BaraBaraya Makassar [Skripsi]. Makassar: Universitas Hasanuddin

Priyoto. (2014) Teori Sikap dan Perilaku dalam Kesehatan. Yogyakarta: Nuha Medika.

Purba, T.R.N. (2012) Faktor - Faktor yang Berhubungan dengan Pemanfaatan Jamkesmas di Wilayah Puskesmas Kota Jambi Tahun 2011. Depok: Fakultas Kesehatan Masyarakat Universitas Indonesia.

Winangsih, R. (2015) Tesis Persepsi Remaja Terhadap Pelayanan Kesehatan Peduli Remaja di Wilayah Puskesmas Kuta Selatan. Denpasar: ProgramPascasarjana Ilmu Kesehatan Masyarakat.

Riskal, Rifat. (2016) Faktor-Faktor yang Berhubungan dengan Mutu Pelayanan Kesehatan pada Pasien di Unit Rawat Inap Rumah Sakit Umum Daerah (RSUD) Ajjapangge Kabupaten Soppeng Tahun 2011 [Skripsi]. Makassar: Universitas Hasanuddin.

Riskesdas. (2015) Laporan Nasional Riset Kesehatan Dasar. Jakarta: Kementerian Kesehatan RI.

Ruga, Novryan. (2016) Hubungan antara Kualitas Pelayanan Kesehatan dengan Minat Penggunaan Ulang Pelayanan Pelayanan Rawat Inap di RSUD Lakipadada Kabupaten Tana Toraja Tahun 2011 [Skripsi]. Makassar: Universitas Hasanuddin.

WHO. (2018) Adolescent Friendly Health Service, An Agenda for Change.

Wijaya, Toni. (2016) Manajemen Kualitas Jasa. Jakarta: PT Indeks. 